\title{
Knowledge, Attitude and Practices Towards Risk Factors for Hypertension in Kinondoni Municipality, Dar es Salaam
}

\author{
Mlunde Linda, MD IV 2006/2007
}

\begin{abstract}
Objective: To assess the people's knowledge, attitudes and practices towards risk factors for hypertension in Kinondoni Municipality.
\end{abstract}

Study design: Cross sectional descriptive study.

Settings: Kimara and Mbezi Luisi wards in Kinondoni Municipality.

Subjects: Adults aged 18 years and above, residents of Kinondoni Municipality at Kimara or Mbezi Luisi.

Results: The number of people included in the study was 318. More than half of the study population (66.80\%) had knowledge on hypertension but only $19.75 \%$ had knowledge on risk factors for hypertension. The common risk factors known were consumption of fatty food and stress. People who reported to be doing physical exercises were 52.35\%, smoking 9.54\% and drinking alcohol $29.56 \%$.

Conclusion: Many people have heard about hypertension but only a few know its risk factors. It is necessary to provide education to people so that they can avoid the risk factors hence reduce the prevalence of hypertension.

Correspondence to: Linda Mlunde +255713279 252

\section{INTRODUCTION}

Hypertension is a blood pressure of $140 / 90$ $\mathrm{mmHg}$ or more, based on at least two readings on separate occasions ${ }^{1}$. Risk factors for hypertension include age, gender (male > female), ethnic origin, diet (especially foods rich in fats ${ }^{2}$, cholesterol ${ }^{3}$, carbohydrates, salt ${ }^{4}$ ), stress, sedentary lifestyle, degree of urbanization ${ }^{4}$, family history ${ }^{5}$, blood cholesterol, diabetes mellitus, pre-existing vascular diseases ${ }^{6}$.

Hypertension can be either primary ('essential') or secondary. Over $90 \%$ of cases are primary. Essential hypertension has a multifactorial aetiology such as genetic factors, fetal factors, environmental factors, humoral mechanisms and insulin resistance. Secondary hypertension may be due to renal causes, endocrine causes, cardiovascular causes, drugs and there might be hypertension in pregnancy ${ }^{1}$.

Elevated blood pressure is usually asymptomatic. Cerebrovascular disease and coronary artery disease are the most common causes of death in hypertension, although these patients are also prone to renal failure and peripheral vascular disease ${ }^{1}$. Stroke, myocardial infarction and cardiovascular death cause mortality associated with high blood pressure ${ }^{7}$.
Management of patients should be considered in three stages: assessment, non-pharmacological treatment and drug treatment. This includes history taking, examination and ambulatory blood pressure monitoring.

All patients should be given advice on nonpharmacological measures including weight reduction, reduction of heavy alcohol intake, salt restriction, regular exercise, avoid smoking.

Antihypertensive drug treatment include diuretics, beta-blockers, angiotensinconverting enzyme (ACE) inhibitors, angiotensin II receptor antagonists, calcium channel blockers, alpha-blockers, vasodilators, centrally acting drugs and other agents like adrenergic neurone blocking drugs such as guanethidine, are used extremely rarely.

A study done in Tanzania year 2000, showed that the prevalence of hypertension was $30 \%$ in men and $28.6 \%$ in women in Ilala, and $32 \%$ in men and $31.5 \%$ in women in Shari. Hypertensive individuals were older, had greater body mass indices and waist: hip ratios, and had more risk factors for hypertension and its complications than non-hypertensive individuals ${ }^{13}$. There is a 
strong positive correlation between blood pressure and body mass index, total serum cholesterol $^{13}$.

Hypertension is the disease in which many people in Tanzania are not aware of it. That is many people don't know that its prevalence is increasing and most of those who know that it is increasing don't put any efforts to avoid its risk factors. There are no any national programmes which control hypertension probably due to low death rate due to hypertension at the moment. This situation is definitely going to change in the future since there is rapid increase in science and technology and the change in people's life styles

The study aimed at determining how many people understand the subject of hypertension and how it is brought about. Knowledge of the effects of hypertension in an individual, family, society and countrywide can motivate people participate fully in hypertension prevention and control.

In addition, the study aimed at determining the way people think of the risk factors to hypertension and if there are any practices in their daily life to reduce occurrence of hypertension cases.

\section{METHODOLOGY}

A cross sectional descriptive study was conducted involving adults aged 18 years and above, residents of Kinondoni Municipality. Multistage sampling was used at ward level where Mbezi luisi and Kimara wards were involved.

A questionnaire was used. Random sampling method was used to get the interviewees. Data was analysed using Epi Info Version 6 soft ware.

Ethical clearance was obtained from the Dean of school of medicine of MUCHS and ethical committee, Ward executive officers of Kimara and Mbezi Luisi. Consent was requested from the interviewees by the researcher. Confidentiality was maintained throughout and after the study.

\section{RESULTS}

A total of 319 people were interviewed, 152 (47.6\%) being females and 167 (52.4\%) being males. More than half of the study population $213(66.8 \%)$ had knowledge on hypertension.

Table 1: People's knowledge on risk factors for hypertension

\begin{tabular}{|l|r|r|r|}
\hline Knowledge & \multicolumn{1}{|l|}{ F } & \multicolumn{1}{l|}{ M } & \multicolumn{1}{l|}{ Total } \\
\hline Yes & $29(27.6 \%)$ & $34(31.5 \%)$ & $63(29.6 \%)$ \\
\hline No & $76(72.4 \%)$ & $74(68.5 \%)$ & $150(70.4 \%)$ \\
\hline Total & $105(100.0 \%)$ & $108(100.0 \%)$ & $213(100.0 \%)$ \\
\hline
\end{tabular}

Only $63(29.6 \%)$ out of 213 people who had knowledge on hypertension.

Table 2: People's practices associating with hypertension

\begin{tabular}{|l|l|l|l|l|}
\hline \multicolumn{2}{|l|}{ Practice } & F & M & Total \\
\hline Exercising & Yes & $\begin{array}{c}50 \\
(29.94 \%)\end{array}$ & $117(70.6 \%)$ & $\begin{array}{l}167 \\
(100.0 \%) \\
(52.35 \%)\end{array}$ \\
\cline { 2 - 5 } & No & $\begin{array}{l}102 \\
(67.11 \%)\end{array}$ & $50(32.89 \%)$ & $\begin{array}{l}152 \\
(100.0 \%) \\
(47.65 \%)\end{array}$ \\
\cline { 2 - 5 } & Total & $\begin{array}{l}152 \\
(47.65 \%)\end{array}$ & $167(52.35 \%)$ & $\begin{array}{l}319 \\
(100.0 \%)\end{array}$ \\
\hline Smoking & Yes & $\begin{array}{l}2 \\
(6.67 \%)\end{array}$ & $28(93.33 \%)$ & $\begin{array}{l}30 \\
(100.0 \%) \\
(9.46 \%)\end{array}$ \\
\hline
\end{tabular}


DMSJ Vol. 14 No. 2

\begin{tabular}{|c|c|c|c|c|}
\hline & No & $\begin{array}{l}149 \\
(51.92 \%)\end{array}$ & $138(48.08 \%)$ & $\begin{array}{l}287 \\
(100.0 \%)\end{array}$ \\
\hline & & & & $(90.54 \%)$ \\
\hline & Total & $\begin{array}{l}151 \\
(47.63 \%)\end{array}$ & $166(52.37 \%)$ & $\begin{array}{l}317 \\
(100.0 \%)\end{array}$ \\
\hline \multirow[t]{3}{*}{ Drinking } & Yes & $\begin{array}{c}32 \\
(34.04 \%)\end{array}$ & $62(65.96 \%)$ & $\begin{array}{c}94 \\
(100.0 \%) \\
(29.56 \%)\end{array}$ \\
\hline & No & $\begin{array}{l}119 \\
(53.13 \%)\end{array}$ & $105(46.87 \%)$ & $\begin{array}{l}224 \\
(100.0 \%) \\
(70.44 \%)\end{array}$ \\
\hline & Total & $\begin{array}{l}151 \\
(47.48 \%)\end{array}$ & $167(52.52 \%)$ & $\begin{array}{l}318 \\
(100.0 \%)\end{array}$ \\
\hline
\end{tabular}

More than half of the study population, 167 $(52.35 \%)$, reported to be doing physical exercises. Only 30 (9.54\%) people reported to be smoking and $94(29.56 \%)$ people reported to be drinking alcohol.

Table 3: Reasons for physical exercising

\begin{tabular}{|l|r|}
\hline Reason & Frequency \\
\hline Like & $39(23.35 \%)$ \\
\hline Reduce weight & $3(1.8 \%)$ \\
\hline Being fit & $122(73.05 \%)$ \\
\hline Other & $3(1.8 \%)$ \\
\hline Total & $167(100.0 \%)$ \\
\hline
\end{tabular}

Other: physical exercising is part of life.

A large number of people 122 (73.05\%), reported to be doing physical exercises so as to be physically fit.

Table 4: Reasons for smoking and drinking alcohol

\begin{tabular}{|l|r|r|}
\hline Reason & \multicolumn{1}{|c|}{ Smoking } & \multicolumn{1}{|c|}{ Drinking } \\
\hline Like & $23(76.67 \%)$ & $73(77.66 \%)$ \\
\hline $\begin{array}{l}\text { Forgetting } \\
\text { problems }\end{array}$ & $4(13.33 \%)$ & $13(13.83 \%)$ \\
\hline Others & $3(10.0 \%)$ & $8(8.51 \%)$ \\
\hline Total & $30(100.0 \%)$ & $94(100.0 \%)$ \\
\hline
\end{tabular}

Others for smoking: being used to smoking and because the partner does smoke while others for drinking: for health, increasing blood and because parents do.

A large number of people were smoking 23 $(76.67 \%)$ and drinking 73 (77.66\%) because they liked doing so.

\section{DISCUSSION}

From the study it was found that $66.8 \%$ of the study population had knowledge on hypertension but only $19.75 \%$ had knowledge on the risk factors for hypertension. This is like the study done in Africa South of the Sahara where it was seen that hypertension and cardiovascular risk factors are not well-known in Burkina Faso population ${ }^{8}$.

Slightly more than half of the study population reported to be doing physical exercises but the number of men $(70.6 \%)$ exercising was found to be more than twice that of women $(29.94 \%)$. This data is like the one in a study done in a newly developed country where the CVD risk factor of obesity was more prominent among women than among men and physical inactivity was predominant among women and found to be highly significant ${ }^{2}$.

The number of people who used to smoke was $30(9.54 \%)$. Out of 30 people only 2 $(6.67 \%)$ women used to smoke. The number of people who used to drink alcohol was $94(29.56 \%)$ but the number of men 62 $(65.96 \%)$ was approaching twice that of women 32 (34.04\%).

This shows that both men and women are predisposed to risk factors of hypertension. The difference is in the types of risk factors as it was seen above that men drink and smoke more compared to women but again males do physical exercises more compared to females

It was found that a large number of people who were doing physical exercises knew its importance. A number of 122 (73.05\%) said they did physical exercises so as to be physically fit. This means many people in the studied settings are at a reduced risk of being hypertensives.

It was also found that many people (53.29\% of those who were not exercising) 
didn't do physical exercises because they had no time to do so due to the types of employments they had. Many people worked the whole day and return to their homes at night tired having no interest of exercising.

A lot of people reported to be smoking (76.67\%) and drinking alcohol (77.66\%) because they liked doing so and only a few did so to forget their problems (average of $13.58 \%$ ). It was also found that a lot of people reported not to be smoking $(63.41 \%)$ or drinking alcohol $(77.66 \%)$ because they didn't like to do so. The people who reported not to be smokind due to risk of diseased was only $24.74 \%$ while those who were not drinking alcohol for that reason was only $11.61 \%$.

This means that many people are not engaged in risk factor behaviours for hypertension like smoking or drinking alcohol because they simply don't like practising those activities. This is dangerous because if they meet with the people who can persuade them to engage in smoking and drinking alcohol, they will easily change their minds as they don't know the risk in smoking and drinking alcohol.

\section{CONCLUSION}

Many people have heard about hypertension but only a few know its risk factors. More than half of the study population were doing physical exercises and many were doing so to be physically fit. A lot of people were not exercising due to lack of time as most of their time was spent in their employments.

A lot of people who were smoking and drinking alcohol did so because they liked and those who didn't, it was because they didn't like doing so. Only a few people didn't smoke or drink alcohol because of risk for diseases.

\section{RECOMMENDATIONS}

People have to be educated through mass media on hypertension and its risk factors. This can be done by having different programmes or articles on the subject. The health workers have to play part by educating the people and also themselves being an example in avoiding the risk factors for hypertension like consumption of fatty food, alcohol and smoking. People have to be educated on the importance of physical exercises and have to be encouraged to do them.

\section{ACKNOWLEDGEMENTS}

I would like to give my sincere gratitude to the dean of school of medicine MUCHS and all the other staff members who helped me achieve this task. My special thanks go to my supervisor Dr. B. Mtinangi who helped throughout the research from the process of proposal writing to report writing. Lastly I would like to thank all the others who helped me in one way or the other in doing this study.

\section{REFERENCES}

1. Kumar P, Clark M. Kumar and Clarks Clinical Medicine. $5^{\text {th }}$ Edition. WB Saunders. Elservier Science Limited, 2002.

2. Bener A et al, The prevalence of hypertension and its associated risk factors in a newly developed country. Saudi Med J. 2004 Jul;25(7):918-22.

3. Njelekela $M$ et al, Cardiovascular risk factors in Tanzania: a revisit. Acta Trop. 2001 Jun 22;79(3):231-9.

4. Daniel HI, Rotimi CN. Genetic epidemiology of hypertension: an update on the African diaspora. Ethn Dis. 2003 Summer;13(2 Suppl 2):S5366.

5. Burket BA. Blood pressure survey in two communities in the Volta region, Ghana, West Africa. Ethn Dis. 2006 Winter; 16(1):292-4.

6. Blood pressure survey in two communities in the Volta region, Ghana, West Africa.

7. Haslett C. et al. Davidson's Principles and Practice of Medicine. $19^{\text {th }}$ Edition. Churchill Livingstone. Harcourt Publishers Limited, 1999.

8. Erdine $S$, Aran SN. Current status of hypertension control around the world. Clin Exp Hypertens. 2004 Oct-Nov; 26(7-8):731-8.

9. Zabsonre $\mathrm{P}$ et al, Knowledge and perception of cardiovascular risk factors in Africa South of the Sahara. Arch Mal Coeur Vaiss. 2002 Jan;95(1):23-8. 